\title{
Digital Spaces, Analogue Thinking: Some Thoughts on Screendance
}

Marisa Zanotti, University of Chichester

\begin{abstract}
With the rapid development of camera technologies and screening platforms over the past 10 years comes an expanded screendance field that opens itself up to new screen bodies, sites, and audiences. Are there new considerations and indeed less-positive effects in this potential? This writing reflects on process, production, and durationnow and in the past-in screendance, performance, and artists' films, to address the question, 'where are we now?'
\end{abstract}

Keywords: democratization, Lisa Nelson, duration, perception, analogue

I'm going to begin with a negative: this writing cannot possibly address the complexity of screendance over the past ten years in all its new and developing manifestations. However, departing from a brief overview of a parallel evolution in film technologies, I'm going to take you on a journey through time, space, and screendance practices and perhaps turn this limitation into a positive.

In the past ten years recording and screening technologies have been getting lighter, smaller, and more affordable and this has had the effect of democratization in many areas of filmmaking and especially in the field of screendance production and distribution. For artists in the field who, either by choice or necessity work outside of a commissioning or funding system and/or had previously found it difficult to access and indeed use technologies, this has been a good thing. Developing screen choreographies is a complex, time-consuming proposition. Now, it's possible to choose to easily move lightweight cameras, rehearse, and perfect camera movement through instant playback, use pre-programmed settings, and shoot immediately in light conditions that until relatively recently would have needed costly equipment and considerable expertise. We can go into locations with smaller, in fact almost invisible, devices with amazing recording capabilities.

\section{Online spaces}

Further to this, the ability to post films online means that screendance festivals, whose entry fees all too often discouraged people of limited means from entering, or people who did not want to participate in festivals for any number of reasons, are no longer the The International Journal of Screendance 10 (2019).

https://doi.org/10.18061/ijsd.v10i0.6569 
only way to show films. Of course screening online is not without its complexities. I am sure I'm not alone in feeling uneasy sharing/creating work on some social media platforms; ${ }^{1}$ online space, like any space, is defined by a set of relations including to capital, to wider questions of politics, censorship, and the information economy and those that trade in it. Nevertheless, the capacity to show online does enable the field to be relevant to a broader spectrum of communities. This continues on from Cara Hagan's eloquent writing in Volume 9 of this journal about creative strategies and affirmative action in curation and dissemination in screendance, and the potential of moving toward "a culture that is a departure from the norms and narratives found in dance, cinema, and museum". ${ }^{2}$

\section{Expanded screen dance practices}

In 2019 screendance artists' practices might include original choreographies developed for the screen, adaptations of existing choreographies, choreographies created in the edit using software programs, and/or all of these artistic choices combined. Alongside the other work that the majority of screendance artists are asked to do, a practice is often a mixture of self-funded, commissioned, and funded work, and a project will often simultaneously include all of these aspects in varying proportions through its development. It's not always possible or desirable to collaborate with cinematographers, editors, designers and sound artists; you might be choosing a more auteurial route or sometimes it's both important and enjoyable to find out about technologies yourself and open up an understanding about the relationships between the tools you can work with and the creative decisions you want to make.

Are there new considerations and indeed less-positive effects in this expanded field of potential? Let's begin by considering bodies and screens: These screen bodies might be dancing bodies, but we might also be thinking about the headless torsos on many dating apps, cyborg bodies with digital tattooing, interfaces in medicine, or the movement activated hoardings of urban spaces where otherworldly entities entice us to join them through a simple, pure act of purchase. How is the field responding creatively and critically to the cultural significance of ways bodies are presented on screens when the phrase 'bodies on screen' now points to any number of signifiers and sites?

There is a strong argument that the most exciting and radical work in dance on screen embodying social critique and evolving technologies is taking place in hip hop and rap: Natty Kasambala's analysis of Donald Glover's This is America (2018) reveals the complexity of the intertextual choreographic language. We might also look to an ongoing exploration of idiosyncratic glitch physicalities in Missy Elliot's collaborations with choreographers such as Sean Bankhead ${ }^{3}$ and Hi-Hat. ${ }^{4}$ In the ecology of this technological landscape, distinctive choreographic bodies are also being produced in 
dances from screens. By this I mean works which are performed live but where screen technologies are embedded in a creative process, integral to the fabric of often longstanding choreographic enquiries. ${ }^{5}$ For example the extreme corporealities of UK choreographer Simon Vincenzi in works like The Surface $(2018)^{6}$ are the result of a film, Alain Resnais' Last Year at Marienbad (1961), being investigated as a closed score in both rehearsal and performance. In The Surface and Vincenzi's earlier work Operation Infinity $(2007-2015)^{7}$ screens and screen languages are present but made visible on stage only through the bodies of performers. Visual exchanges in screen languages between camera, performer, and viewers are also considered as a choreographic strategy in Lea Anderson's Edits (2015), where a queer gaze meets audiences through what appears to be a direct address to the audience but is derived from the queer gaze of director Rainer Werner Fassbinder's The Bitter Tears of Petra Von Kant (1972). Chicago's AToM-R developed yet another way of exploring embodiment and screens in Field Anatomy $(2013)^{8}$ when they created interfaces where dancers' bodies could be physically read by the audience through bespoke QR codes.

Whether dances from screens or dances on screens, what unites these projects is a critical examination of relationships between bodies and technologies that has resulted in radical corporealities; this bodes well for screendance being relevant to broader audiences. Unfortunately, what is more usual in the field is that-unless the work is an adaptation of an existing choreography-it's difficult outside of the commercial sector to get the time to develop the movement element of a screendance in any depth beyond initial research and development. While technologies are definitely cheaper, dancers still need to be paid, and perhaps as a result screendances often have small casts. Additionally screendance can still be marked by a tendency to fall into what the screen-artist and choreographer Mary Wycherly describes as "a trap of beautifying the body." ${ }^{\prime \prime}$ It's possible to work with dancers with what feels like limitless technical capabilities or dancers who are skilled improvisers, and perhaps as a result it can be easy to quickly generate a kind of screendance mirage whose glossy surface and unthreatening content could easily be at home in the rhetoric of advertising, seducing viewers with a spectacle of silent dancing bodies. ${ }^{10}$

\section{Time, speed and ease?}

All of these questions and thoughts lead me to consider what might have been left to the side in my own filmmaking. I have noticed something in my own practice, and that of peers, that speaks to an expression of economics of time and spaces and an experience of labor. I'm questioning the speed at which I'm working, the amount I'm shooting on digital formats either alone or with a crew, the increasing pace within my edits, and the pressures I'm putting myself under in order to produce more and more 'product.' Have ideas of speed and ease become interpolated as desirable values in the experience of production, process, and viewing of screendance as much as in the film 
industry outside of screendance? And if so, do we as a community really want that to be the case? As an artist who moved from working with analogue film and video technologies to a digital screen practice, I have been reflecting on the connection between technologies and process, and what I might bring to my own practice from my previous 'analogue thinking' where I shot less, planned more, made fewer images, and edited on paper. I'm going to consider time in both process and outcome, and in order to do this I will begin outside of screendance with a work made on film that deals with duration ... and see where this path takes me.

\section{Time, attention, and rhythm}

In 1967 the Canadian artist Michael Snow made Wavelength. He shot it in one week having prepared the shoot for a year. The film is 45 minutes and appears to be a single unbroken zoom shot to the far wall of a loft space. The key sound is a sine wave that increases in intensity as the film develops through what Snow describes as "four human events". ${ }^{11}$ Snow plays with perception through work with sound and vision, narrative, and simple action. Wavelength does initially feel challenging, so unfamiliar is its duration. Snow asks us to invest time and a willingness to surrender his desire to take you somewhere uncertain. I emerged from watching Wavelength altered, my internal rhythm slowed down in the space it produced. My return to the rhythms of an everyday world felt clumsy, like I imagine an astronaut would feel coming back from space. A similar effect took place when I watched Jonathan Glazer's Under The Skin (2014: 108 mins) or most recently The Fits (2015: 71 minutes) written about in this journal in Volume 9. ${ }^{12}$ The films I have cited are not screendances although they are open for readings in relation to choreographic mise-en-scéne: their narrative structures resonate with the vertical narratives of screendance, ${ }^{13}$ and at their centre are ideas of corporealities; for example alien bodies (Under The Skin) and bodies that may or may not be possessed (The Fits). These filmmakers ask an audience to be willing to put aside not only normative ways of watching a film, but also that we attend to the world outside the film differently; think again about how we look. In my screen work they invite me to consider the development of unique structures for perception.

\section{Perception and Lisa Nelson}

\section{I'll begin with looking}

The filmmaker and historian Mark Cousins' recent book The Story of Looking ${ }^{14}$ explores looking as a cultural practice, and might be read alongside similar enquiries by John Berger on seeing in visual art, Laura Marks' work on intercultural experience and perception in film, or Maurice Merleau-Ponty's philosophy investigating vision and perception. ${ }^{15}$ As a filmmaker, Cousins' thinking on different ways filmmakers look-the gestures of looking we make-took me back to an idea in relation to dance practice. For 
dance artists, looking occupies a particular role in perceptual experience as a whole and perhaps a heightened awareness that the gesture of looking, like all gestures, does not happen independently of other gestures and actions. The work of American pyschologist J. J. Gibson is relevant here. He posited that perception is not a passive reception of information through a sense organ but an active process undertaken by the perceiver in response to their internal (sensory/kinaesthetic) and external environments, and further that perception is made up of the interactions between the senses. For example, vision is a stream of information actively gathered through the eye, but in response to feedback from all the senses. ${ }^{16}$ Artist-researcher and videographer Lisa Nelson has a long-term project on perception drawn from Gibson's writing. One idea she explores is the role of embodiment in looking, she says of her initial experiments with video:

When I put a camera to my head, I wasn't doing it like a robot, where my brain was on a tripod. I put it to my head and I was struck with how I moved my head following my interest through this frame. It reflected my way of relating to my body and the environment. I work with the medium of video through my kinesthetic sense. In dancing, working without the camera, I find that when I shift into vision, just looking at light and form, I don't have any desire to move. ${ }^{17}$

Rather than immediately thinking about what you might be seeing through the viewfinder, Nelson's approach suggests a different way of thinking about making moving-image work. Her project defines a specific kind of screen production process, one of studio explorations, aligning the making of screendance with performancemaking processe. ${ }^{18}$ In a further investigation of perception Nelson also uses exploratory viewing strategies in her research. One of her techniques shared in workshops includes developing an awareness of the kind of looking we do when we watch the same thing twice. A second viewing of a film often reveals something that was not visible first time around. These exercises demand a discipline that's often to do with taking longer to decide what we have seen than we are used to. Nelson's work highlights the kinds of habits we might have as viewers and invites me to ask how spectatorial experiences and viewing 'habits' might be produced in screendance.

For example, when Hamish McPherson wrote that screendance to his outsider eye seemed to be defined by "established forms and boundaries and requirements"19 one of those forms relates to time. The call for papers for this volume ${ }^{20}$ asked where do we find ourselves as a field? It is of course difficult to say where screendance is right now but wherever we might want to go, we probably need to arrive there in 7 - 12 minutes. ${ }^{21}$ We might also want to consider getting there in 30 seconds on Instagram, under 45 seconds on Twitter, under 1 minute if we are screening on Facebook, or a leisurely 2 minutes on YouTube; that is if we want an online audience to remain with $\mathrm{us}^{22}$ as anyone knows from the sometimes heartbreaking statistics for finished plays for work 
you've screened online. ${ }^{23}$ In the case of social media, duration is all about keeping us interested enough to stay on a platform; but of course it's also in the interest of the platform and its sponsors that we are not so interested in what we are currently watching that we don't pay attention to the many other things simultaneously available. Shorter time frames are not necessarily a barrier to creating affecting new durations. As quantum physics tells us, time is relative, time in the edit is malleable and there are some fine examples in our field of short-form work. ${ }^{24}$ There is also an argument that the short form model of screendance work speaks to current practice in the dance field in how dance is shared online in a culture that encourages artists to make both performance and process visible as product through social media networks and other public platforms. As McPherson comments:

... I only have to look around at my peers and see they are already making short films and putting them online, and these are part of their practice and their work as much as dancing and writing and talking and all kinds of things. ${ }^{25}$

In theory this wave of screen activity could expand the audience for screendance and open up new paradigms such as the way that Hagan uses Instagram strategically at ADF. ${ }^{26}$ It can be argued that the data flow of social media is not unlike the short form programs of a screendance festival. Although, after reflecting on Lisa Nelson's double viewing practice, I'm wondering now if I can re-calibrate the way that I deal with festival programs. I'm thinking about whether there might be possibilities of going back to watch a program again, and what that would do to my experience of the work. Of course, this takes time.

So short form is not all bad, but might it now be time for a serious discussion about longer form screendance works: Who gets to make them? What challenges do they present? What viewing contexts frame them best? The field is probably ready for looking at what creative innovations and technical and dramaturgical solutions have been developed by screendance artists such as Stanley Wong with Dance Goes On (2017) in the development of long form works with vertical narratives. Might it be worth looking to duration in Dash's Daughters of The Dust (1991) or mise-en-scéne in Lucrecia Martel's Zama (2017) or in cinematographer Babette Mangolte's significant collaborations with both Chantal Akerman and Yvonne Rainer? ${ }^{27}$

Returning to where are we now and where might we go next, there are exciting projects strategically developing a more diverse community of young screen artists; for example the UK's Random Acts with Channel $4,{ }^{28}$ and in the US Marcus White and Carlos Funn's Moving $24 p s .{ }^{29}$ Screendance and choreographic artists are bringing knowledges and conceptual frameworks from the dance studio into aspects of filmmaking in different ways, but much of this work remains undocumented. I would be interested to hear in depth about how this is taking place, particularly in cinematography by dance-trained 
camera operators and in sound recording and mixing; areas which remain underresearched in screendance. The field now encompasses augmented reality, gallery work, streaming on dedicated dance channels, curated online screenings, pay per view, playlists, work on social media, work by subscription, transmedia projects, hyperchoreographies and content that is crowd sourced and opensource. These contexts all operate differently through the ways they suggest relationships between bodies, spaces, and screens, and invite different artistic propositions and problems in how we locate viewers and ourselves as makers. How will the evolution of screendance account for the bodies and gestures these complex corporeal mise-en-scènes ${ }^{30}$ invite? Which screenic ${ }^{31}$ languages will respond to, resist, belong to, or lead the continuing evolution of our mediated bodily experiences? The opportunity for screendance to evolve significantly is full of potential and in more immediate reach than ever before.

\section{Biography}

Marisa Zanotti is an award-winning filmmaker who has been exploring ideas around bodies, screens and perception through analogue and digital technologies since the 1990 s in different kinds of projects. Her work is informed by her background in performance, choreography, theatre and installation practices. She has a long-term collaboration with the editor lan Ballantyne and has created screen dance projects with choreographers including Ben Wright (2012) and Lea Anderson (The Pan's People Papers (2015), Edits Film (2014). Recent projects include the VR installation project We Are All Made of Stars, a collaboration with classical composer Matthew Whiteside, a Magnetic North commission with funding from Arts Council England. In 2018 her video projection commissioned by Whiteside for his string quartet Entangled opened the Northern Ireland Science Festival (2018) and won the Light Moves award for Innovative Use of Sound. Current research interests include the parallel development of spiritualism and technologies and embodied cognition and the role of choreographic knowledges in the development of Mixed Reality (MR) experiences. She is currently writing a monograph based on her practice-led doctoral research that explores adapting dance to screens. Marisa is a Reader in Digital Technologies and Choreography at University of Chichester.

Email:m.zanotti@chi.ac.uk

Website: www.marisazanotti.net 


\section{Notes}

${ }^{1}$ Disclosure: I made a Transmedia work, The Pan's People Papers on Facebook and Twitter in 2015 http://panspeoplepapers.com.

${ }^{2}$ Cara Hagan, Curatorial Practices for Intersectional Programming.

${ }^{3}$ https://www.YouTube.com/watch?v=TwyPsUd9LAk.

${ }^{4}$ https://www.YouTube.com/watch?v=Q33ujOhLV-E.

${ }^{5}$ See also Harmony Bench's investigation into other iterations of dances from screens in relation to feedback loops and sites of experimentation in what she terms 'social dance-media'. Harmony Bench Screendance 2.0: Social Dance-Media 183-214.

${ }^{6}$ https://www.simonvincenzi.com/the-surface-video.

${ }^{7}$ http://operationinfinity.org.

${ }^{8}$ https://vimeo.com/67282359.

${ }^{9}$ Mary Martha Wogan, Interview: Mary Wycherly Dance artist and choreographer

${ }^{10}$ This is not to say that advertising has not produced some memorable choreographic moments centred in dance: recent examples include space opening up to FKA Twigs in Spike Jonze's work for Apple (2018) YouTube https://youtu.be/305ryPvU6A8, Mikhail Baryshnikov's sinister cool set against Lil'Buck's speed ramped jookin' in Rag and Bone's 2015 men's project https://youtu.be/2rFRTyfwBH8 and the creepy possession of Gene Kelly's body by breakdancers for Volkswagen (2005)

https://vimeo.com/7775155.

${ }^{11}$ Gloria Moure, Michael Snow: Sequences - A History of His Art, 123.

${ }^{12}$ Elena Benthaus, Dis/Orientation: Rhythmic Bodies and Corporeal Orature in The Fits

${ }^{13}$ Chirstinn Whyte, A Choreographic Sensibility,

${ }^{14}$ Mark Cousins, The Story of Looking.

15 John Berger, Ways of Seeing, Laura Marks, The Skin of The Film, Maurice MerleauPonty, The Phenomenology of Perception.

${ }^{16}$ Melinda Buckwalter, Composing While Dancing, 144.

${ }^{17}$ Lisa Nelson, The Sensation is the Image. 
${ }^{18}$ Nelson's teaching laboratories reveal perception as a whole and that for a dancer, corporeal perception, that is sensing space and action through the whole body often supplements, or indeed takes the place, of vision. Employing corporeal perception often features in different ways in the processes of screen artists.

${ }^{19}$ Hamish McPherson, What Are Screendance Competitions Even For?

${ }^{20}$ Harmony Bench and Simon Ellis, International Journal of Screendance Volume 10: "Screendance Now" Open Call For Papers.

${ }^{21}$ While some screendance festivals will invite proposals for longer works, the majority continue to specify a duration of under 15 minutes and usually shorter works will have a significantly higher chance of being selected for inclusion in a programme.

${ }^{22}$ Chi Clifford, https://blog.hubspot.com/marketing/how-long-should-videos-be-oninstagram-twitter-facebook-YouTube

${ }^{23}$ The need to keep us in a flow of information online operates in a similar way to the need to keep us from changing television channels in the days before streaming. The reality is that this requirement affects both duration and content and in the screen dances of the late 1980s and 1990s in the UK was one factor that led to not just short form but also narrative being the dominant form in screendance. Jordan and Allen's anthology Parallel Lines (1993) offers an important insight into the history of dance on television in the UK.

${ }^{24}$ Filomena Rusiciano: Liquid Path https://vimeo.com/74490969, Evan Seibens, Time Reversal Symmetry: http://evannsiebens.com/time-reversal-symmetry.

${ }^{25}$ Hamish McPherson, idem.

${ }^{26}$ https://www.instagram.com/adfsmoviesby.

${ }^{27}$ Chantal Akerman. Un Jour Pina A Demandé, Yvonne Rainer. Lives of The Performers

${ }^{28}$ https://randomacts.channel4.com/tagged/featured-collection.

${ }^{29}$ http://moving24fps.com/creatives/ see also Marcus White Narrative Shifts: Race, Culture and the production of Screendance, http://screendancejournal.org/article/view/6049.

${ }^{30}$ Erin Brannigan, Dancefilm: Choreography and The Moving Image, 183.

${ }^{31}$ Douglas Rosenberg, Screendance: Inscribing the Ephemeral Image, 45. 


\section{References}

Adams Sitney, Paul. Visionary Film. New York: Oxford University Press, 1974.

Bench, Harmony. "Screendance 2.0: Social Dance-Media." Participations: Journal of Audience and Reception Studies 7.2 (November 2010): 183-214.

Bench, Harmony and Ellis, Simon. "International Journal of Screendance Volume 10: 'Screendance Now' Open Call For Papers" 21 May 2018.

https://screendance.wordpress.com/2018/05/21/international-journal-ofscreendance-volume-10-screendance-now-open-call-for-papers.

Benthaus, Elena. "Dis/Orientation: Rhythmic Bodies and Corporeal Orature in The Fits." The International Journal of Screendance 9 (2018).

https://doi.org/10.18061/ijsd.v9i0.6220

Berger, John. Ways of Seeing. London: Penguin, 2008.

Brakhage, Stan. Stan Brakhage: Metaphors on Vision. USA: McPherson and Co., 2001.

Brannigan, Erin. Dancefilm: Choreography and the Moving Image. New York: Oxford University Press, 2011. https://doi.org/10.1093/acprof:oso/9780195367232.001.0001

Buckwalter, Melinda. Composing While Dancing: An Improviser's Companion. Madison, WI: University of Wisconsin Press, 2010.

Cousins, Mark. The Story of Looking. Edinburgh: Canongate, 2017.

Chi, Clifford. "How long should videos be on instagram twitter facebook YouTube?" 22 April 2018. Accessed 12 September 2018 https://blog.hubspot.com/marketing/howlong-should-videos-be-on-instagram-twitter-facebook-YouTube.

Ching-A- Ling. Dir. Dave Myers and Missy Elliot. Choreography: Hi-Hat. 2008. YouTube. https://youtu.be/Q33ujOhLV-E.

Dance Goes On. Dir. Stanley Wong, Choreographer Hugh Cho. Film. Vimeo. https://vimeo.com/239810326.

Daughters of The Dust. Dir. Julie Dash. 1991. Netflix.

Field Anatomy. AToM-R. Performance. 2014. Vimeo. https://vimeo.com/67282359.

Hagan, Cara. "Curatorial Practices for Intersectional Programming" International Journal of Screendance 9 (2018). https://doi.org/10.18061/ijsd.v9i0.6046

Homepod: The new sound of home. Dir. Spike Jonze. 2018. YouTube. https://youtu.be/305ryPvU6A8. 
I'm Better. Dir. Dave Myers ad Missy Elliot. Choreography: Sean Bankhead and Missy Elliot. 2018. YouTube. https://youtu.be/TwyPsUd9LAk.

Jordan, Stephanie. and Allen, David. eds. Parallel Lines. London: John Libbey and Company Ltd, 1993.

Kasambala, Natty. "Unpacking all the references in Childish Gambino's phenomenal new video." 7 May 2018. Accessed 11 September 2018. http://www.dazeddigital.com/music/article/39966/1/childish-gambino-this-isamerica-meaning-jim-crow-dancing-liberty.

Marks, Laura. The Skin of The Film: Intercultural Cinema, Embodiment and The Senses. Durham and London: Duke University Press, 2000.

McPherson, Hamish. "What Are Screendance Competitions Even For? A Response to the 2015 Leeds International Film Festival Screendance Competition." International Journal of Screendance 6 (2016). https://doi.org/10.18061/ijsd.v6i0.5063

Merleau Ponty, Maurice. The Phenomenology of Perception. London, Routledge, 2002 Moure, Gloria. Michael Snow: Sequences - A History of His Art. Barcelona, Ediciones Poligrafia, 2015.

Moving 24fps Screendance Projects. Accessed 24 February 2019. http://moving24fps.com/creatives.

Nelson, Lisa. The Sensation is the Image: Writings on Dance No. 14 (Summer 1995-96). Accessed 9 September 2018 http://sarma.be/docs/3248.

Rag and Bone: Men's Fall Winter 2015. Dir. Georgie Greville. Advert. 2015. YouTube https://youtu.be/2rFRTyfwBH8.

Last Year at Marienbaad. Dir. Alain Resnais. Film. 1961. Cocinor.

Liquid Path. Dir. Filomena Rusiciano. Film. 2014. Vimeo https://vimeo.com/74490969.

Lives of The Performers. Dir. Yvonne Rainer. Film. 1972. Zeitgeist Films.

Operation Infinity. Dir/Choreographer. Simon Vincenzi. Web Artefact. 2007-2015 http://operationinfinity.org Accessed 9 September 2018.

Random Acts. https://randomacts.channel4.com/tagged/featured-collection Channel 4 UK.

Rosenberg, Douglas. Screendance: Inscribing the Ephemeral Image. New York: Oxford University Press, 2007. https://doi.org/10.1093/acprof:oso/9780199772612.001.0001

The Fits. Dir. Anna Rose Holmer. Film. 2015. Netflix. 
This is America. Dir. Hiro Murai. 2018. YouTube. https://youtu.be/ddJqNY_9U8.

The Pan's People Papers. Dir. Marisa Zanotti, Choreographer Lea Anderson Transmedia. 2015. http://panspeoplepapers.com.

Time Reversal Symmetry. Dir. Evan Siemens. Film. 2018. http://evannsiebens.com/timereversal-symmetry.

Tuffnell, Miranda and Crickmay, Chris. Body, Space, Image: Dance Books: Hampshire, 1990.

Under the Skin. Dir. Jonathan Glazer. Film. 2014. Netflix.

Un Jour Pina A Demandé. Dir. Chantal Akerman. Film. 1986, RAI.

Vincenzi, Simon. https://www.simonvincenzi.com/the-surface-video. Accessed 29 January 2019.

VW Golf GTI Singin' In The Rain. Dir. NEO. Advert. 2010. Vimeo https://vimeo.com/7775155.

Wogan, Mary Martha. Interview: Mary Wycherly Dance artist and choreographer: Accessed 4 February 2019. https://marywycherley.com/invisible-histories.

Wavelength. Dir. Michael Snow. Film. 1967. YouTube https://www.YouTube.com/watch?v=aBOzOVLxbCE.

White, Marcus. "Narrative Shifts: Race, Culture and the production of Screendance." The International Journal of Screendance 9 (2018). https://doi.org/10.18061/ijsd.v9i0.6049

Whyte, Chirstinn. A Choreographic Sensibility (Unpublished PhD thesis) University of Middlesex, 2007. Available at http://www.shiftwork.org.uk/unspooled_site/thesis.

Zama. Dir. Lucrecia Martel. Film. 2017. Walt Disney Studios. 